\title{
Trends in Snag Populations in Drought-Stressed Mixed-Conifer and Ponderosa Pine Forests (1997-2007)
}

\author{
Joseph L. Ganey and Scott C. Vojta \\ Rocky Mountain Research Station, US Forest Service, 2500 S. Pine Knoll, Flagstaff, AZ 86001, USA \\ Correspondence should be addressed to Joseph L. Ganey, jganey@fs.fed.us
}

Received 16 June 2011; Revised 16 November 2011; Accepted 6 December 2011

Academic Editor: Andrew Gray

Copyright ( $) 2012$ J. L. Ganey and S. C. Vojta. This is an open access article distributed under the Creative Commons Attribution License, which permits unrestricted use, distribution, and reproduction in any medium, provided the original work is properly cited.

\begin{abstract}
Snags provide important biological legacies, resources for numerous species of native wildlife, and contribute to decay dynamics and ecological processes in forested ecosystems. We monitored trends in snag populations from 1997 to 2007 in drought-stressed mixed-conifer and ponderosa pine (Pinus ponderosa Dougl. ex Laws) forests, northern Arizona. Median snag density increased by 75 and $90 \%$ in mixed-conifer and ponderosa pine forests, respectively, over this time period. Increased snag density was driven primarily by a large pulse in drought-mediated tree mortality from 2002 to 2007, following a smaller pulse from 1997 to 2002. Decay-class composition and size-class composition of snag populations changed in both forest types, and species composition changed in mixed-conifer forest. Increases in snag abundance may benefit some species of native wildlife in the short-term by providing increased foraging and nesting resources, but these increases may be unsustainable in the long term. Observed changes in snag recruitment and fall rates during the study illustrate the difficulty involved in modeling dynamics of those populations in an era of climate change and changing land management practices.
\end{abstract}

\section{Introduction}

Snags (standing dead trees) provide important biological legacies, resources for numerous species of native wildlife, and contribute to decay dynamics and ecological processes in the forests where they occur [1-4]. Because of their importance, snags have received considerable attention from land managers and researchers [5-8]. Data on snag numbers and densities often are sparse, however. Further, snag dynamics are poorly understood in most forest types and geographic areas [9] and typically exhibit large spatial and temporal variability $[10,11]$.

To address information needs relative to dynamics of snag populations in southwestern mixed-conifer and ponderosa pine (Pinus ponderosa Dougl. ex Laws) forests, we established a series of permanent plots in north-central Arizona in 1997 and resampled all plots in 2002 and 2007. This interval overlapped with a period of severe, global climate-change type drought (defined here as a drought accompanied by warmer temperatures [12]) in this area [12-14], providing an opportunity to monitor the effects of drought-mediated tree mortality [15]. Ganey and Vojta [16] summarized changes in snag populations from 1997 to 2002, but this captured only changes during the early and less-severe phase of this drought. Here, we quantify accelerated changes that occurred from 2002 to 2007 during a period of intensifying drought and following a particularly warm and dry year in 2002 (see [17, 18]). Specifically, we (1) summarize changes in snag density and basal area from 1997 to 2002 and 2002 to 2007, (2) describe changes in composition (decay, size-class, and species distributions) of snag populations, and (3) summarize patterns in snag recruitment. The changes in snag populations documented here during a warm, dry period may provide a glimpse of changes likely under predicted future climate scenarios in the southwestern United States [14, 19, 20].

\section{Study Area}

The study area encompassed approximately 73,000 ha within the Coconino and Kaibab National Forests, north-central Arizona (Figure 1). Within this area, study plots were 

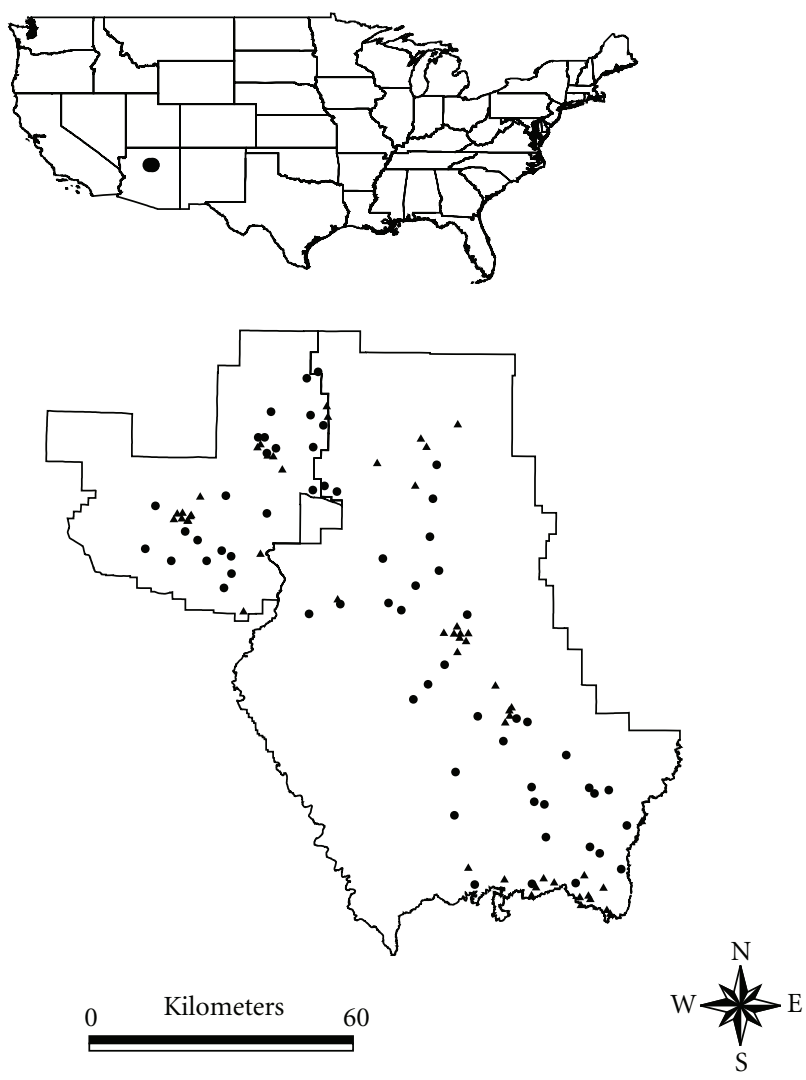

Figure 1: Location of the study area (black box, top) in northern Arizona, USA, and locations of snag-monitoring plots within the study area (bottom). Plots were located in the Kaibab (left) and Coconino (right) National Forests, north-central Arizona. Plots in ponderosa pine forest $(n=60)$ are indicated by circles, plots in mixed-conifer forest $(n=53)$ by triangles.

randomly located in mixed-conifer and ponderosa pine forest. Mixed-conifer forests were dominated numerically by ponderosa pine, white fir (Abies concolor Lindl. ex Hildebr.), and Douglas-fir (Pseudotsuga menziesii (Mirb.) Franco), which together accounted for approximately $90 \%$ of total trees in this forest type [15]. Other species included Gambel oak (Quercus gambelii Nutt.), quaking aspen (Populus tremuloides Michaux), and limber pine (P. flexilis James), in that order of frequency. Ponderosa pine accounted for over $90 \%$ of trees in ponderosa pine forest [15]. Gambel oak also was relatively common (approximately $8 \%$ of total trees by frequency), and alligator juniper (Juniperus deppeana Steud), Douglas-fir, quaking aspen, limber pine, pinyon pine (P. edulis), and other species of juniper were present in small numbers in some stands.

The study plots were distributed across a wide range of topographic conditions and soil types. They covered the entire elevational range of these forest types within this area, from the transition zone between pinyon-juniper woodland and ponderosa pine at lower elevations to the ecotone between mixed-conifer and Engelmann spruce (Picea engelmannii Parry ex Engelm.) — corkbark fir (Abies lasiocarpa var. arizonica (Merriam) Lemmon) forests at higher elevations
[21]. Plots also included both commercial forest lands and administratively reserved lands such as wilderness and other roadless areas. Consequently, plots represented a wide range of forest structural conditions. For example, as of 2004, density of trees $\geq 20 \mathrm{~cm}$ in diameter at breast height ( $\mathrm{dbh}$ ) ranged from 78 to 489 (median $=266.7$ ) trees/ha in mixedconifer forest and from 11 to 689 (median $=227.8)$ trees/ha in ponderosa pine forest, and basal area ranged from 7 to 52 $($ median $=25.2)$ and from 1 to $44($ median $=19.7) \mathrm{m}^{2} /$ ha in mixed-conifer and ponderosa pine forest, respectively [15].

\section{Methods}

3.1. Field Sampling. We sampled snags on a set of 113 plots ( 1 ha each in area) randomly established in 1997 (see [22] for details). We sampled all snags $\geq 2 \mathrm{~m}$ in height and $\geq 20 \mathrm{~cm}$ in diameter at breast height (dbh) in 1997, 2002, and 2007. We did not sample smaller-diameter snags based on the assumption that these were less important to cavity-nesting birds [23-27] and/or roosting bats [28-30]. All snags were uniquely marked with numbered metal tags, allowing us to distinguish existing snags from new snags when resampling plots. For all snags, we recorded snag species, dbh, and decay class. Snag diameter was recorded to the nearest $\mathrm{cm}$ using a dbh tape. Decay classes recognized followed Raphael and White [31].

3.2. Data Analysis. We focused analyses within rather than between forest types, because we were interested primarily in trends over time within forest type. We relied on nonparametric statistical tests [32], because distributions for many snag parameters deviated greatly from normality. We present medians and ranges as estimates of central tendency and variability, because many parameters were highly skewed so that a few plots greatly influenced mean estimates.

No plots underwent commercial timber harvest between 1997 and 2007. Three ponderosa pine plots underwent thinning of smaller trees during this period, two ponderosa pine plots underwent prescribed fire, and five plots experienced intense wildfire (two in mixed-conifer and three in ponderosa pine forests). We included all plots in summarizing snag numbers and composition of snag populations because our objective was to quantify these parameters across the landscape, including recently disturbed areas. We excluded plots that experienced severe wildfire when summarizing recruitment patterns, however, because intense wildfire melted the metal tags used to mark snags [16], making it difficult to determine whether dead trees represented new mortality or preexisting snags.

We summarized data on changes in density and basal area of snags and composition of snag populations from 1997 to 2002 and 2002 to 2007 . We examined both density and basal area because both parameters are useful in different contexts. For example, guidelines for snag retention for wildlife frequently are presented in terms of snag density $[5,6]$, whereas basal area is useful in the context of forest management. We compared snag density and basal area across years (1997, 2002, and 2007) using the Friedman test [32]. Where that 
test indicated overall differences across years, we compared pairs of years (1997 versus 2002 and 2002 versus 2007) using Wilcoxon signed-ranks test (essentially a two-sample equivalent of the Friedman test [32]), to determine which years differed. We set the $P$ value for significance in all omnibus tests at $<0.05$ and at $(0.05 /$ number of comparisons) for all multiple comparisons.

Because intense wildfires could influence trends in snag density across years, we used Mann-Whitney tests [32] to compare snag density in 2007 between plots that had and had not experienced intense wildfire prior to that time. Where results of those tests indicated that 2007 snag density differed between burned and unburned plots, we repeated the Friedman test discussed above using only unburned plots to factor out the influence of wildfire on snag density across years.

We compared decay- and size-class distributions and species composition of snag populations across years using chi-square tests [32]. Where decay-class distributions or species composition differed across years, we subdivided chisquare analyses to determine which years differed from one another. Where size-class distributions differed across all years, we compared diameter distributions directly between pairs of years (1997 and 2002, 2002 and 2007, and 1997 and 2007), using Kolmogorov-Smirnov tests [32] (hereafter referred to as K-S tests), to determine where differences occurred.

We also evaluated differences in composition of populations of snags recruited in two time intervals, 1997 to 2002 and 2002 to 2007. Specifically, we compared species composition and diameter distributions of these newly recruited snags between the specified intervals, using chisquare tests and K-S tests, respectively.

We estimated snag fall rate as the percentage of snags existing at the beginning of a specified time interval that fell before the end of that interval. We compared snag fall rates between time intervals (1997 to 2002 and 2002 to 2007) using the test for comparing two proportions described by Zar [33] (essentially an analogue of a chi-square test).

\section{Results}

4.1. Changes in Snag Density and Basal Area. Median snag density increased by $75 \%$ in mixed-conifer forest from 1997 to 2007 (Figure 2; Friedman test, $P<0.001$ ). Density differed between both 1997 and 2002 and between 2002 and 2007 in this forest type (Wilcoxon tests, both $P$ values $<0.001$ ). Density of snags in 2007 did not differ between plots that experienced intense wildfires and plots that did not experience such fires in mixed-conifer forest (MannWhitney test, $P=0.471, n=2$ and 51 plots, resp.).

Median snag density increased by $90 \%$ in ponderosa pine forest from 1997 to 2007 (Figure 2; Friedman test, $P<0.001)$. Snag density did not differ between 1997 and 2002 in ponderosa pine forest $(P=0.103)$, but increased significantly from 2002 to 2007 (Figure 2; $P<0.001$ ). Snag density in ponderosa pine forest in 2007 was significantly greater (Mann-Whitney test, $P=0.014$ ) in plots burned by

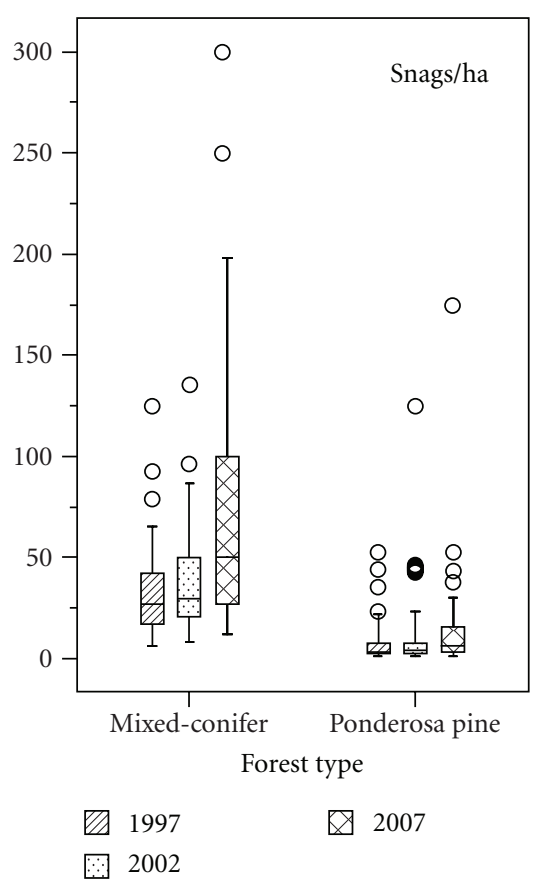

Figure 2: Trends in density (snags/ha) of snags in northern Arizona mixed-conifer and ponderosa pine forest, 1997 to 2007. Boxes indicate the interquartile range (25th to 75 th percentile), the line within the box indicates the median, and the external lines show the range in the data excluding outliers (circles, defined as observations more than 1.5 box lengths outside the box).

intense wildfires $\left(\right.$ median $=41$ snags $\mathrm{ha}^{-1}$, range $=14$ to 173 snags $\left.\mathrm{ha}^{-1}, n=3\right)$ than in plots not burned by such fires (median $=9$ snags ha ${ }^{-1}$, range $=1$ to 47 snags ha $^{-1}$, $n=57)$. Snag density increased significantly across years even in unburned plots, however (Friedman test, $P<0.001$ ).

Median snag basal area increased by approximately $45 \%$ in both forest types (Figure 3; Friedman tests, both $P$ values $<0.001)$. Snag basal area differed between both 1997 and 2002 and 2002 and 2007 in both forest types (Wilcoxon tests, both $P$ values $<0.001$ in mixed-conifer forest; both $P$ values $<0.010$ in ponderosa pine forest). Spatial variation in both snag density and basal area was relatively pronounced, as indicated by high variability among plots (Figures 2 and 3 ).

Increases in snag density and basal area were driven primarily by a large pulse in snag recruitment from 2002 to 2007 and not by decreases in snag fall rates among time intervals. Snag recruitment from 2002 to 2007 was approximately $200 \%$ and $74 \%$ greater than snag recruitment from 1997 to 2002 in mixed-conifer and ponderosa pine forest, respectively. In contrast, snag fall rates were greater from 2002 to 2007 than from 1997 to 2002 in both forest types (both $P$ values $<0.001$ ). Fall rates increased from 20.5 to $27.3 \%$ in mixed-conifer forest and from $34.2 \%$ to $43.5 \%$ in ponderosa pine forest (increases of 33.2 and $27.2 \%$, resp.).

4.2. Changes in Composition of Snag Populations. The large pulse in snag recruitment from 2002 to 2007, along with a smaller pulse in the period from 1997 to 2002, resulted 


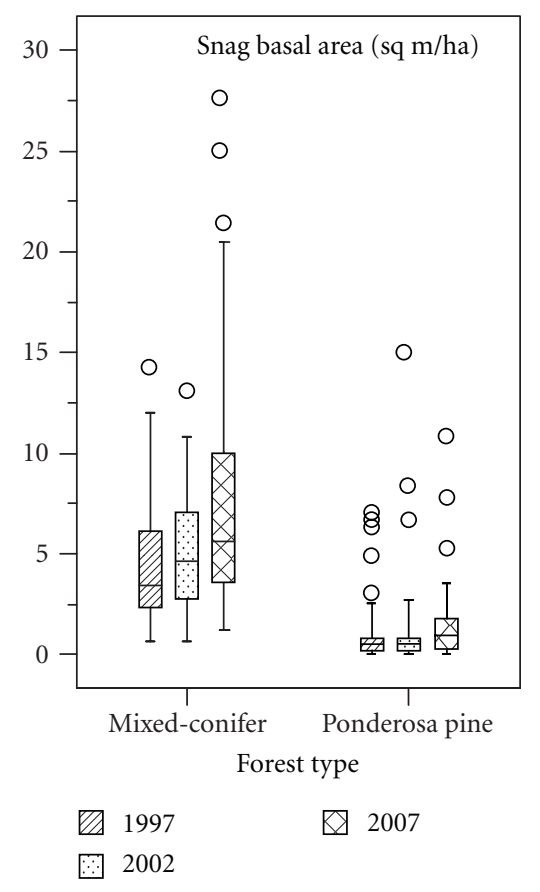

Figure 3: Trends in basal area $\left(\mathrm{m}^{2} / \mathrm{ha}\right)$ of snags in northern Arizona mixed-conifer and ponderosa pine forest, 1997 to 2007. Boxes indicate the interquartile range (25th to 75 th percentile), the line within the box indicates the median, and the external lines show the range in the data excluding outliers (circles, defined as observations more than 1.5 box lengths outside the box).

in marked changes in composition of snag populations. For example, because most snags enter the population in decay classes 1 or 2 [16], the influx of large numbers of new snags shifted decay-class composition in both forest types from a distribution dominated by snags in older decay classes (classes 4 and 5) in 1997 to a distribution dominated by snags in younger decay classes (classes 1 and 2) in 2007 (Figure 4; $P<0.001$ in both forest types, chi-square tests). Pairwise comparisons indicated that decay-class distributions differed among all years in both forest types (all $P$ values $<0.001$ in both forest types).

Snag density increased in all size classes in both forest types between 1997 and 2007 (Figure 5), and size-class distributions changed significantly in both forest types over this time period (chi-square tests, $P<0.001$ and $<0.025$ in mixed-conifer and ponderosa pine forest, resp.). Pairwise K$S$ tests indicated that diameter distributions did not differ significantly $(P>0.05)$ between 1997 and 2002 in either forest type but differed significantly between 2002 and 2007 in both forest types (both $P$ values <0.001). By 2007, proportions of snags in smaller size classes increased and proportions in the largest size classes decreased in both forest types (Figure 5). This shift primarily was driven by greater recruitment of snags in the smaller size classes from 2002 to 2007 (Figure 6). Diameter distributions of snags recruited from 2002 to 2007 differed significantly from those of snags recruited from 1997 to 2002 in both forest types (K-S tests, $P<0.001)$ and were skewed toward smaller diameter snags.

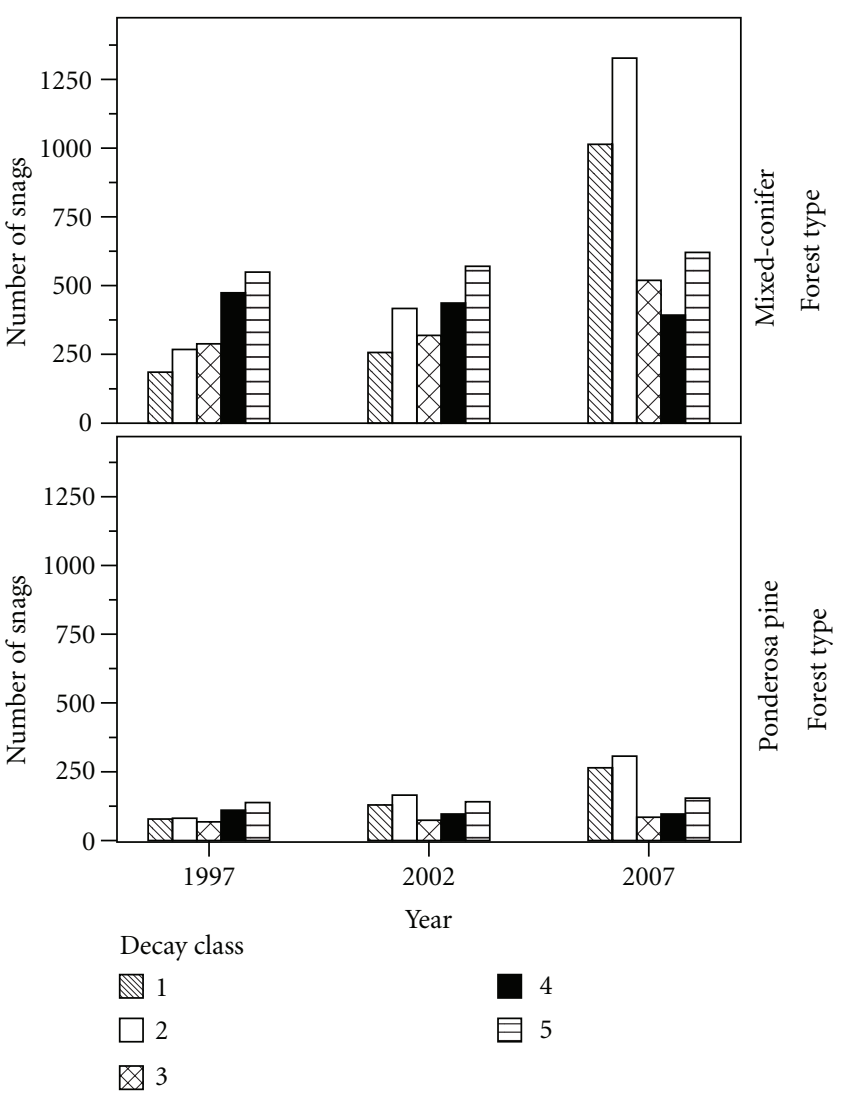

FIGURE 4: Decay-class composition of snags in northern Arizona mixed-conifer and ponderosa pine forest in 1997, 2002, and 2007. Snags in decay class 1 retained needles (or leaves), twigs, and intact limbs. Decay-class 2 snags retained twigs and intact limbs but lacked needles (or leaves). Class 3 snags had limbs that were largely intact but lacked twigs. Class 4 snags had limbs that were mostly broken, and class 5 snags lacked large limbs entirely. In both forest types, decay-class distributions shifted from dominance by snags in later decay classes (classes 4 and 5) in 1997 to snags in early decay classes (classes 1 and 2) in 2007.

Snag density also increased for all tree species (or species groups; Figure 7). Species composition of snag populations changed significantly from 1997 to 2007 in mixed-conifer forest (chi-square test, $P<0.001$ ). Pairwise comparisons indicated that species composition in this forest type did not differ between 1997 and $2002(P>0.05)$ but differed significantly $(P<0.001)$ between 2002 and 2007. The proportion of white fir snags in mixed-conifer forest more than doubled from 1997 to 2007, with most of that increase occurring between 2002 and 2007. Proportions of ponderosa pine and Gambel oak snags declined during this period. These changes were driven by recruitment patterns, which differed significantly (chi-square test, $P<0.001$ ) between the periods 1997 to 2002 and 2002 to 2007 (Figure 8). In particular, a huge pulse in recruitment of white fir snags occurred between 2002 and 2007. Although tree mortality increased in all tree species during this period [15], recruitment of white fir snags swamped all other species.

In ponderosa pine forest, species composition of snag populations did not change significantly from 1997 to 2007 


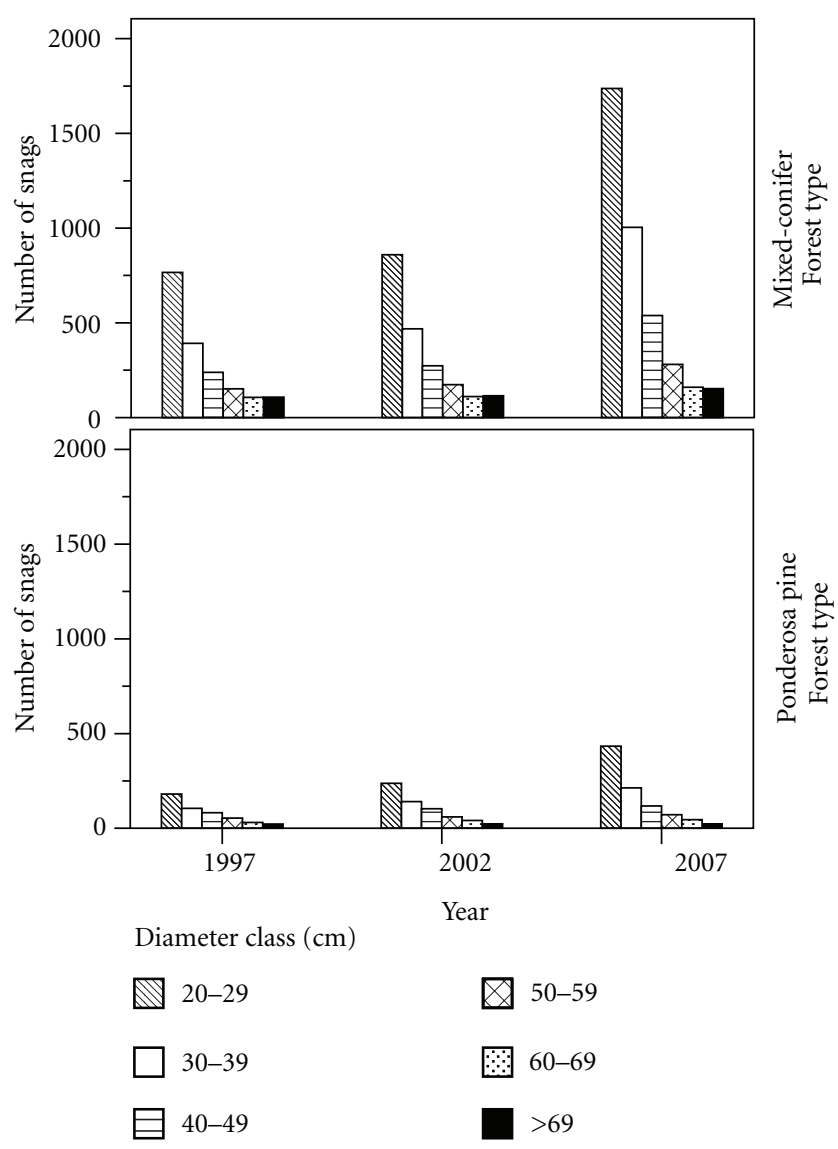

FIGURE 5: Size-class distribution of snags in northern Arizona mixed-conifer and ponderosa pine forest in 1997, 2002, and 2007. Absolute numbers of snags increased in all size classes in both forest types. In contrast, proportions of snags generally increased in the smaller size classes and decreased in the larger size classes in both forest types.

(chi-square test, $P>0.05$ ). Snag populations in all years were heavily dominated by ponderosa pine and secondarily by Gambel oak in this forest type (Figure 7). Species composition of snags recruited from 1997 to 2002 differed from composition of snags recruited from 2002 to 2007 in ponderosa pine forest (Figure 8; chi-square test, $P<0.001$ ), but the difference was not large enough to significantly alter species composition of standing snags. The primary differences between time periods were greater recruitment of Douglas-fir snags from 1997 to 2007 and greater recruitment of Gambel oak snags from 2002 to 2007 (Figure 8).

\section{Discussion}

Snag populations in both forest types studied here increased markedly from 1997 to 2007, a period of global-climate change type drought [12]. Most of that increase was driven by increased snag recruitment (e.g., tree mortality), as snag longevity did not increase during the study and in fact declined during the latter half of the study. Much of the observed snag recruitment appeared to be due to droughtmediated mortality [15], operating in conjunction with a

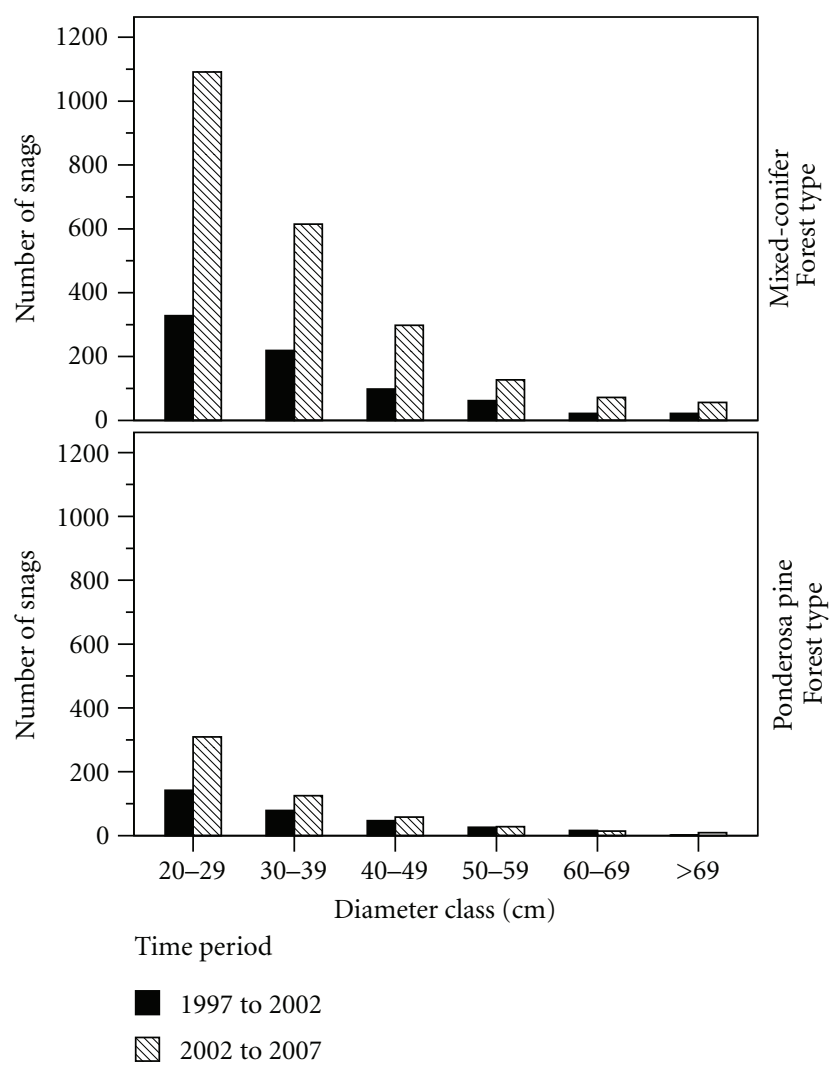

Figure 6: Number of snags recruited by diameter class in northern Arizona mixed-conifer and ponderosa pine forests from 1997 to 2002 and from 2002 to 2007. Recruitment occurred across all size classes and was greater in most size classes from 2002 to 2007 than from 1997 to 2002 . Recruitment during the latter period especially was concentrated in the smaller size classes.

suite of forest insects that included bark beetles (primarily Ips spp.), Douglas-fir beetles (Dendroctonus pseudotsugae), and fir engravers (Scolytus ventralis [34]). Wildfire also affected snag density in ponderosa pine forest, but its effects were limited to only a few plots, in contrast to climate-related mortality that occurred on most plots.

Increased tree mortality in the latter half of this study (2002 to 2007) followed an extreme climate year in 2002 $[17,18]$. Whether this increased mortality was caused by the effects of that extreme climate year or reflected the cumulative effects of longer-term drought remains unknown. Either way, it appears to portend increased mortality in the future. Most climate models predict increases in both temperature and aridity in the southwestern US $[14,19,20]$. Both long-term droughts and extremely warm and dry years are predicted to be more common, and both are likely to result in increases in tree mortality [12, 14, 18, 35-38]. Consequently, snag populations should continue to increase in these systems in the near future.

Observed changes in snag populations have a number of implications. In the short term, the observed increase in snag numbers should benefit some species of native wildlife. The large number of dead and dying trees should provide abundant foraging substrates for species such as 


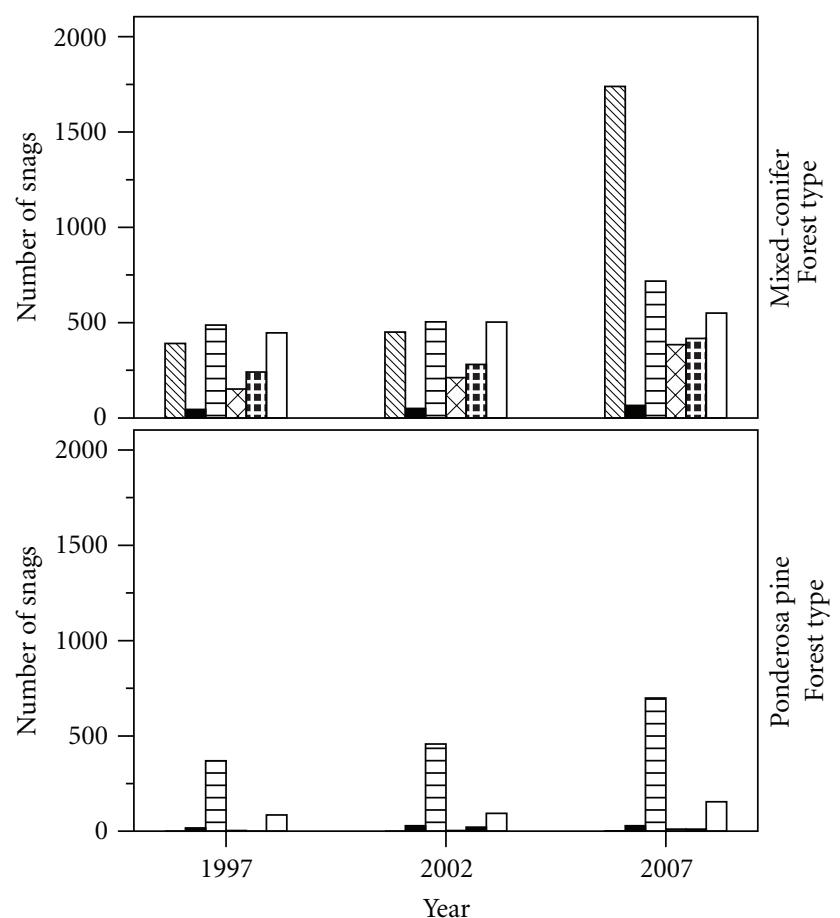

Species

$\begin{array}{ll}\mathbb{Q} \text { ABCO } & \text { POTR } \\ \square \text { OTHR } & \text { \# PSME } \\ \text { 目 PIPO } & \square \text { QUGA }\end{array}$

Figure 7: Species composition of snag populations in northern Arizona mixed-conifer and ponderosa pine forest in 1997, 2002, and 2007. Species acronyms: ABCO: white fir, PIPO: ponderosa pine, POTR: quaking aspen, PSME: Douglas-fir, QUGA: Gambel oak, and OTHR: all other species.

woodpeckers that forage on dead or dying trees [39-45]. This should be particularly true where snags occur in high densities $[41,45,46]$; these high densities may be necessary to support populations of some woodpeckers that forage on insects in dead and dying trees $[7,46]$.

Snags also provide an important nesting resource for cavity excavators (primarily woodpeckers (Piciformes) in this study area [47]) and secondary cavity-nesting birds in this region $[23,25,48]$, as well as roost and maternity sites for bats [28-30]. The short-term effect of changes in snag populations on nesting and roosting resources is less clear, however. Snag numbers increased in all species and size classes, suggesting potential gains in these resources. But the majority of new snags were smaller in diameter than snags typically used by cavity-nesting birds and bats in this and other areas [24-30,41,46, 47, 49], and the most abundant species of new snags in mixed-conifer forest was white fir, which is used infrequently by cavity-nesting birds [47]. This suggests that many of the newly created snags may not possess the features that attract cavity-nesting birds and roosting bats. Further, fall rates of snags increased during the second half of this study as mortality increased. Consequently, many of these newly created snags may not

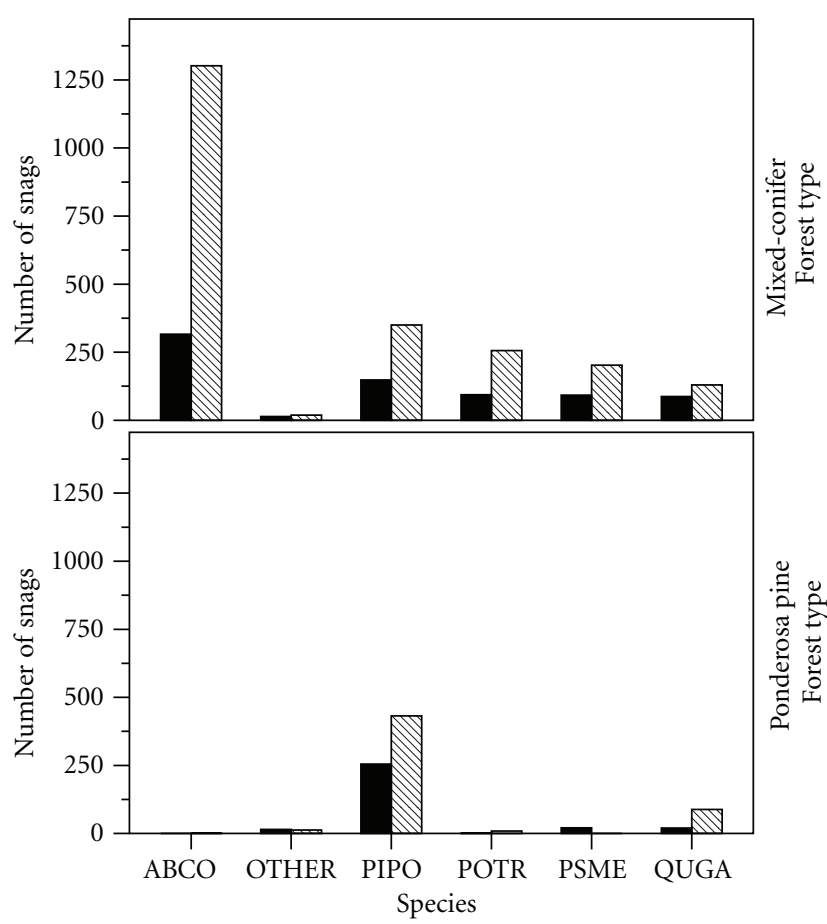

$$
\begin{aligned}
& \text { Time period } \\
& \square \quad 1997 \text { to } 2002 \\
& \mathbb{\mathbb { }} 2002 \text { to } 2007
\end{aligned}
$$

FIGURE 8: Number of snags recruited by snag species in northern Arizona mixed-conifer and ponderosa pine forest from 1997 to 2002 and from 2002 to 2007. Species acronyms: ABCO: white fir, PIPO: ponderosa pine, POTR: quaking aspen, PSME: Douglas-fir, QUGA: Gambel oak, and OTHER: all other species. Recruitment occurred in all species and increased for most species between 2002 and 2007 but was especially pronounced for white fir in mixed-conifer forest.

remain standing long enough to provide nest sites for cavity-nesting birds [42] or roost sites for bats.

In the longer term, the observed trends in tree mortality may be detrimental to cavity-nesting birds and bats [44, 50], as current levels of mortality appear to be great enough to reduce the future supply of mature trees significantly, especially in mixed-conifer forest [15]. Further, mortality rates could increase if regional climate tends toward higher temperatures and greater aridity $[12,14,36-38]$. Such rapid reductions in the numbers of live trees could greatly reduce sources of future snags in this forest type. Spatial variability in mortality was pronounced, however, so this reduction would not occur equally across the landscape. Thus, sources of future snags would be greatly reduced in some, but not all, areas.

Observed changes in snag populations will affect fuel loads as well. Many stands now feature large numbers of standing dead trees, with many of these trees falling over relatively short time periods. These falling snags will result in a relatively large input of surface fuels in these systems. This large increase in surface fuels could create challenges for fire and fuels managers. Tree mortality also is reducing canopy density and continuity, however, which may reduce 
the potential for spread of crown fires. This balance between increased surface fuels and decreased canopy fuels will drive changes in fire behavior, likely will vary greatly across the landscape given the pronounced spatial variability observed in tree mortality [15], and also may vary with time since disturbance [51]. Thus, the net effect of this fuels pulse on fire behavior in these systems is unknown at present.

The rapid increase in snag recruitment observed from 2002 to 2007, as well as changes in snag longevity during this period, illustrates some of the problems involved in attempting to model dynamics of snag populations in the face of temporal variability $[11,52]$. This complexity is exacerbated by the effects of climate change and potential changes in disturbance regimes and land management practices. Predicted changes in climate and land management practices may affect both snag recruitment and snag longevity, either directly or through complex interactions with disturbance regimes and mortality agents [42, 53-55]. As a result, models based on snag recruitment and fall rates from past periods are unlikely to describe current and future dynamics of snag populations adequately.

\section{Acknowledgments}

The authors thank J. Jenness, G. Martinez, M. Stoddard, B. Strohmeyer, R. White, and, especially, A. and J. Iníguez for their assistance in establishing plots, and L. Doll, D. and N. Ganey, and C. Vojta for assistance with plot sampling. For assistance with initial plot selection, they thank J. Ellenwood, B. Higgins, K. Menasco, C. Nelson, and G. Sheppard (Kaibab National Forest) and C. Beyerhelm, A. Brown, H. Green, T. Randall-Parker, C. Taylor, and M. Whitney (Coconino National Forest). L. S. Bagget provided advice on statistical analyses, and C. L. Chambers, R. L. Hutto, M. L. Morrison, V. A. Saab, and two anonymous reviewers commented on earlier versions of this paper.

\section{References}

[1] M. E. Harmon, J. F. Franklin, F. J. Swanson et al., "Ecology of coarse woody debris in temperate ecosystems," Advances in Ecological Research, vol. 15, pp. 133-302, 1986.

[2] E. L. Bull, C. G. Parks, and T. R. Torgersen, "Trees and logs important to wildlife in the interior Columbia River basin," Tech. Rep. PNW-391, USDA Forest Service, 1997.

[3] W. McComb and D. Lindenmayer, "Dying, dead, and down trees," in Maintaining Biodiversity in Forest Ecosystems, M. L. Hunter Jr., Ed., pp. 335-372, Cambridge University Press, Cambridge, UK, 1999.

[4] W. F. Laudenslayer Jr., P. J. Shea, B. E. Valentine, C. P. Weatherspoon, and T. E. Lisle, "Proceedings of the symposium on the ecology and management of dead wood in western forests," Tech. Rep. PSW-GTR-181, USDA Forest Service, 2002.

[5] M. L. Morrison, M. F. Dedon, M. G. Raphael, and M. P. YoderWilliams, "Snag requirements of cavity-nesting birds: are USDA Forest Service guidelines being met?" Western Journal of Applied Forestry, vol. 1, pp. 38-40, 1986.

[6] K. Mellen, B. G. Marcot, J. L. Ohmann et al., "DecAID: a decaying wood advisory model for Oregon and Washington," in Proceedings of the Symposium on the Ecology and Management of Dead Wood in Western Forest, W. F. Laudenslayer Jr., P. J. Shea, B. E. Valentine, C. P. Weatherspoon, and T. E. Lisle, Eds., USDA Forest Service Gen. Tech. Rep. PSW-GTR-181, pp. 527-533, 2002.

[7] R. L. Hutto, “Toward meaningful snag-management guidelines for postfire salvage logging in North American conifer forests," Conservation Biology, vol. 20, no. 4, pp. 984-993, 2006.

[8] B. G. Marcot, J. L. Ohmann, K. L. Mellen-McLean, and K. L. Waddell, "Synthesis of regional wildlife and vegetation field studies to guide management of standing and down dead trees," Forest Science, vol. 56, no. 4, pp. 391-404, 2010.

[9] R. Everett, J. Lehmkuhl, R. Schellhaas et al., "Snag dynamics in a chronosequence of 26 wildfires on the east slope of the Cascade Range in Washington State, USA," International Journal of Wildland Fire, vol. 9, no. 4, pp. 223-234, 2000.

[10] M. G. Raphael and M. L. Morrison, "Decay and dynamics of snags in the Sierra Nevada, California," Forest Science, vol. 33, pp. 774-783, 1987.

[11] M. L. Morrison and M. G. Raphael, "Modeling the dynamics of snags," Ecological Applications, vol. 3, no. 2, pp. 322-330, 1993.

[12] D. D. Breshears, N. S. Cobb, P. M. Rich et al., "Regional vegetation die-off in response to global-change-type drought," Proceedings of the National Academy of Sciences of the United States of America, vol. 102, no. 42, pp. 15144-15148, 2005.

[13] J. L. Weiss, C. L. Castro, and J. T. Overpeck, "Distinguishing pronounced droughts in the southwestern United States: seasonality and effects of warmer temperatures," Journal of Climate, vol. 22, no. 22, pp. 5918-5932, 2009.

[14] A. P. Williams, C. D. Allen, C. I. Millar et al., "Forest responses to increasing aridity and warmth in the southwestern United States," Proceedings of the National Academy of Sciences of the United States of America, vol. 107, no. 50, pp. 21289-21294, 2010.

[15] J. L. Ganey and S. C. Vojta, "Tree mortality in drought-stressed mixed-conifer and ponderosa pine forests, Arizona, USA," Forest Ecology and Management, vol. 261, no. 1, pp. 162-168, 2011.

[16] J. L. Ganey and S. C. Vojta, "Changes in snag populations in northern Arizona mixed-conifer and ponderosa pine forests, 1997-2002," Forest Science, vol. 51, no. 5, pp. 396-405, 2005.

[17] M. W. Salzer and K. F. Kipfmueller, "Reconstructed temperature and precipitation on a millennial timescale from tree-rings in the southern Colorado Plateau, U.S.A," Climatic Change, vol. 70, no. 3, pp. 465-487, 2005.

[18] D. F. Koepke, T. E. Kolb, and H. D. Adams, "Variation in woody plant mortality and dieback from severe drought among soils, plant groups, and species within a northern Arizona ecotone," Oecologia, vol. 163, no. 4, pp. 1079-1090, 2010.

[19] R. Seager, M. Ting, I. Held et al., "Model projections of an imminent transition to a more arid climate in southwestern North America," Science, vol. 316, no. 5828, pp. 1181-1184, 2007.

[20] R. Seager and G. A. Vecchi, "Greenhouse warming and the 21st century hydroclimate of southwestern North America," Proceedings of the National Academy of Sciences of the United States of America, vol. 107, no. 50, pp. 21277-21282, 2010.

[21] D. E. Brown, C. H. Lowe, and C. P. Pase, "A digitized systematic classification for ecosystems with an illustrated summary of the natural vegetation of North America," Tech. Rep. RM-73, USDA Forest Service, 1980. 
[22] J. L. Ganey, "Snag density and composition of snag populations on two National Forests in northern Arizona," Forest Ecology and Management, vol. 117, no. 1-3, pp. 169-178, 1999.

[23] R. P. Balda, "The relationship of secondary cavity nesters to snag densities in western coniferous forests," Wildlife Habitat Technical Bulletin 1, USDA Forest Service, Southwestern Region, Albuquerque, NM, USA, 1975.

[24] V. E. Scott, "Characteristics of ponderosa pine snags used by cavity-nesting birds," Journal of Forestry, vol. 76, pp. 26-28, 1987.

[25] J. B. Cunningham, R. P. Balda, and W. S. Gaud, "Selection and use of snags by secondary cavity-nesting birds of the ponderosa pine forest," Tech. Rep. RM-222, USDA Forest Service, 1980.

[26] P. Li and T. E. Martin, "Nest-site selection and nesting success of cavity-nesting birds in high-elevation forest drainages," Auk, vol. 108, pp. 405-418, 1991.

[27] C. J. Conway and T. E. Martin, "Habitat suitability for Williamsons's sapsuckers in mixed-conifer forests," Journal of Wildlife Management, vol. 57, no. 2, pp. 322-328, 1993.

[28] M. J. Rabe, T. E. Morrell, H. Green, J. C. Devos, and C. Richard Miller, "Characteristics of ponderosa pine snag roosts used by reproductive bats in northern Arizona," Journal of Wildlife Management, vol. 62, no. 2, pp. 612-621, 1998.

[29] D. A. Bernardos, C. L. Chambers, and M. J. Rabe, "Selection of Gambel oak roosts by southwestern myotis in ponderosa pine-dominated forests, northern Arizona," Journal of Wildlife Management, vol. 68, no. 3, pp. 595-601, 2004.

[30] B. G. Solvesky and C. L. Chambers, "Roosts of Allen's lappet-browed bat in Northern Arizona," Journal of Wildlife Management, vol. 73, no. 5, pp. 677-682, 2009.

[31] M. G. Raphael and M. White, "Use of snags by cavity-nesting birds in the Sierra Nevada," Wildlife Monographs, vol. 86, pp. $1-66,1984$.

[32] W. J. Conover, Practical Nonparametric Statistics, John Wiley \& Sons, New York, NY, USA, 2nd edition, 1980.

[33] J. H. Zar, Biostatistical Analysis, Prentice-Hall, Inglewood Cliffs, NJ, USA, 2nd edition, 1984.

[34] USDA Forest Service, "Forest insect and disease conditions in the southwestern Region, 2008,". Forestry and Forest Health PR-R3-16-5. USDA Forest Service, Southwestern Region. Albuquerque, NM, USA, October 2009, http://www.fs.fed.us/ r3/publications/documents/fidc2008.pdf.

[35] D. D. Breshears, O. B. Myers, C. W. Meyer et al., "Tree die-off in response to global change-type drought: mortality insights from a decade of plant water potential measurements," Frontiers in Ecology and the Environment, vol. 7, no. 4, pp. 185$189,2009$.

[36] H. D. Adams, M. Guardiola-Claramonte, G. A. Barron-Gafford et al., "Temperature sensitivity of drought-induced tree mortality portends increased regional die-off under globalchange-type drought," Proceedings of the National Academy of Sciences of the United States of America, vol. 106, no. 17, pp. 7063-7066, 2009.

[37] J. F. Negrón, J. D. McMillin, J. A. Anhold, and D. Coulson, "Bark beetle-caused mortality in a drought-affected ponderosa pine landscape in Arizona, USA," Forest Ecology and Management, vol. 257, no. 4, pp. 1353-1362, 2009.

[38] C. D. Allen, A. K. Macalady, H. Chenchouni et al., "A global overview of drought and heat-induced tree mortality reveals emerging climate change risks for forests," Forest Ecology and Management, vol. 259, no. 4, pp. 660-684, 2010.
[39] J. L. Blackford, "Woodpecker concentration in burned forest," Condor, vol. 57, pp. 28-30, 1955.

[40] J. R. Koplin, "The numerical response of woodpeckers to insect prey in a subalpine forest in Colorado," Condor, vol. 74, pp. 436-438, 1969.

[41] C. L. Chambers and J. N. Mast, "Ponderosa pine snag dynamics and cavity excavation following wildfire in northern Arizona," Forest Ecology and Management, vol. 216, no. 1-3, pp. 227-240, 2005.

[42] K. L. Farris and S. Zack, "Woodpecker-snag interactions: an overview of current knowledge in ponderosa pine systems," in Proceedings of the Symposium on Ponderosa Pine: Issues,. Trends, and Management, M. W. Ritchie, D. A. Maguire, and A. Youngblood, Eds., pp. 183-195, USDA Forest Service, 2005, USDA Forest Service General Technical Report PSW-GTR198.

[43] K. A. Covert-Bratland, W. M. Block, and T. C. Theimer, "Hairy woodpecker winter ecology in ponderosa pine forests representing different ages since wildfire," Journal of Wildlife Management, vol. 70, no. 5, pp. 1379-1392, 2006.

[44] K. Martin, A. Norris, and M. Drever, " Effects of bark beetle outbreaks on avian biodiversity in the British Columbia interior: implications for critical habitat management," $B C$ Journal of Ecosystems and Management, vol. 7, no. 3, pp. 1024, 2006.

[45] C. T. Hanson and M. P. North, "Postfire woodpecker foraging in salvage-logged and unlogged forests of the Sierra Nevada," Condor, vol. 110, no. 4, pp. 777-782, 2008.

[46] V. A. Saab, R. E. Russell, and J. G. Dudley, "Nest-site selection by cavity-nesting birds in relation to postfire salvage logging," Forest Ecology and Management, vol. 257, no. 1, pp. 151-159, 2009.

[47] J. L. Ganey and S. C. Vojta, "Characteristics of snags containing excavated cavities in northern Arizona mixed-conifer and ponderosa pine forests," Forest Ecology and Management, vol. 199, no. 2-3, pp. 323-332, 2004.

[48] J. D. Brawn and R. P. Balda, "Population biology of cavity nesters in northern Arizona: do nest sites limit breeding densities?" Condor, vol. 90, pp. 61-71, 1988.

[49] S. P. Horton and R. W. Mannan, "Effects of prescribed fire on snags and cavity-nesting birds in southeastern Arizona pine forests," Wildlife Society Bulletin, vol. 16, no. 1, pp. 37-44, 1988.

[50] W. E. Stone, The impact of a mountain pine beetle epidemic on wildlife habitat and communities in post-epidemic stands of a lodgepole pine forest in northern Utah, Ph.D. thesis, Utah State University, Logan, Utah, USA, 1995.

[51] M. Simard, W. H. Romme, J. M. Griffin, and M. G. Turner, "Do mountain pine beetle outbreaks change the probability of active crown fire in lodgepole pine forests?" Ecological Monographs, vol. 81, no. 1, pp. 3-24, 2011.

[52] R. E. Russell, V. A. Saab, J. G. Dudley, and J. J. Rotella, "Snag longevity in relation to wildfire and postfire salvage logging," Forest Ecology and Management, vol. 232, no. 1-3, pp. 179187, 2006.

[53] R. L. Peters, "Effects of global warming on forests," Forest Ecology and Management, vol. 35, no. 1-2, pp. 13-33, 1990.

[54] D. McKenzie, Z. Gedalof, D. L. Peterson, and P. Mote, "Climatic change, wildfire, and conservation," Conservation Biology, vol. 18, no. 4, pp. 890-902, 2004.

[55] T. J. Parker, K. M. Clancy, and R. L. Mathiasen, "Interactions among fire, insects and pathogens in coniferous forests of the interior western United States and Canada," Agricultural and Forest Entomology, vol. 8, no. 3, pp. 167-189, 2006. 

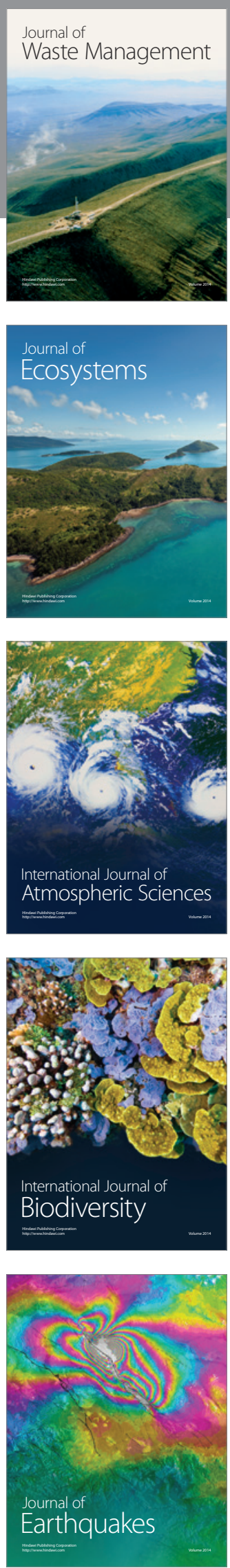
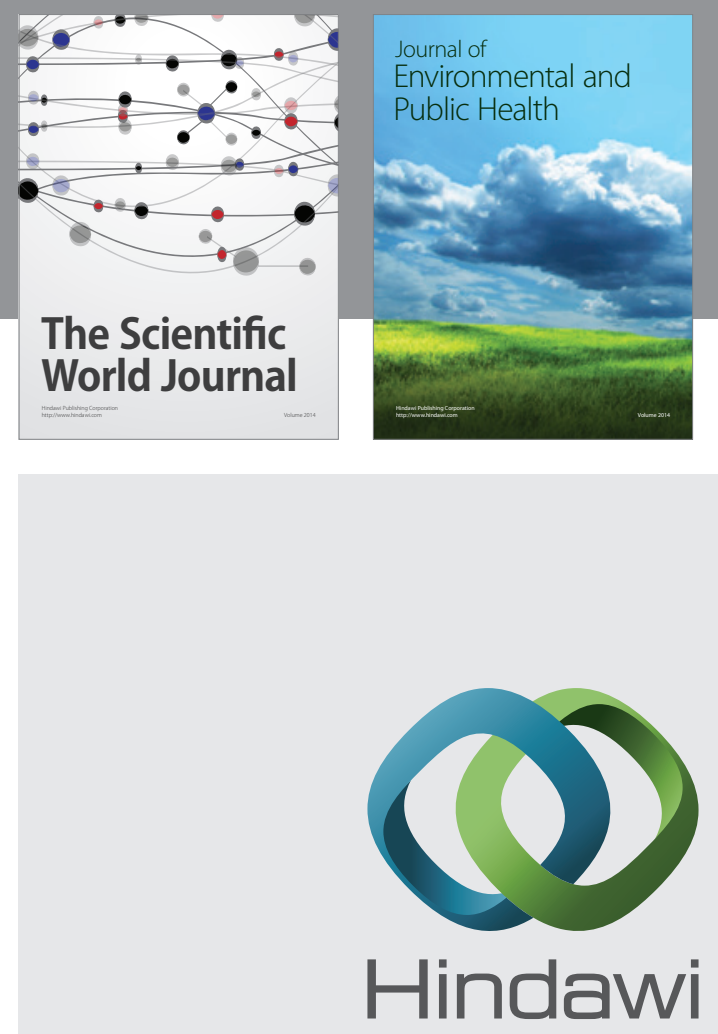

Submit your manuscripts at

http://www.hindawi.com
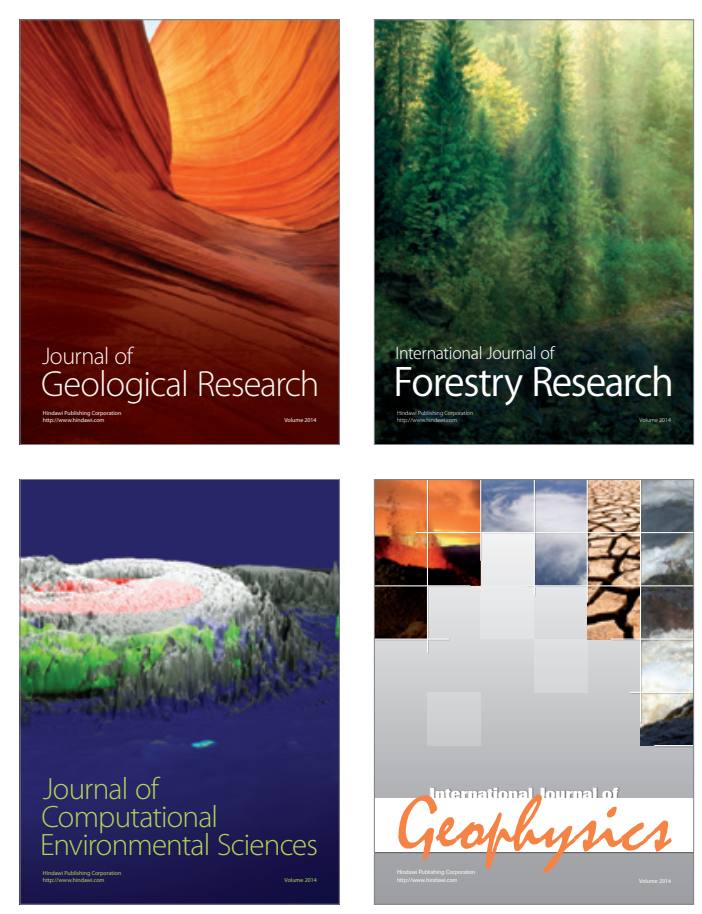
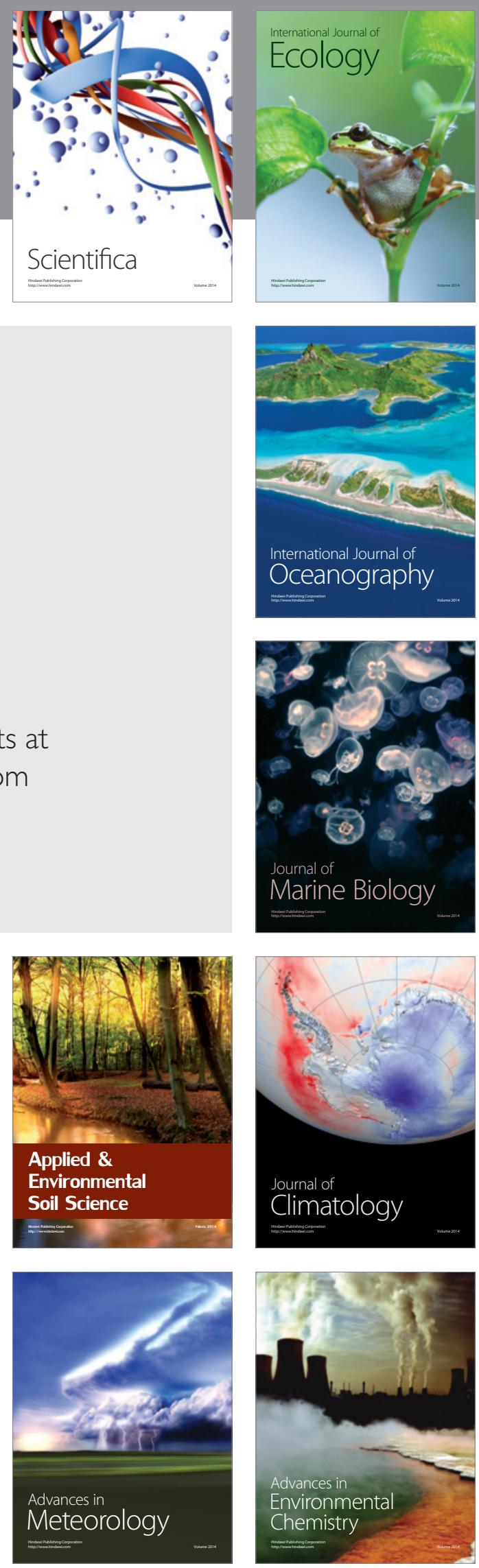